\title{
ORTHOGONAL CUTTING FORCES IN JUVENILE AND MATURE PINUS TAEDA WOOD
}

\author{
Raquel Gonçalves ${ }^{1 *}$; Antônio Carlos Néri² \\ ${ }^{1}$ UNICAMP/FEAGRI - Laboratório de Materiais e Estruturas, C.P. 6011 - Cidade Universitária Zeferino Vaz s/n - \\ 13083-875 - Campinas, SP - Brasil. \\ ${ }^{2}$ Universidade do Planalto Catarinense, Av. Castelo Branco, 170 - 88509-900 - Lages, SC - Brasil. \\ *Correspondingauthor <raquel@agr.unicamp.br>
}

\begin{abstract}
The distinct characteristics of juvenile and mature woods, which are observed particularly in softwoods, have an influence on processing due to their different mechanical resistance properties in relation to cutting operations. In the past, when most of the wood used industrially came from adult trees of natural forests, little importance was given to a distinction between different zones of the tree stem. At present, however, as the supply of mature trees with large diameters from native forests is constantly decreasing, the use of short-cycle trees has become a common practice, through the adoption of species that grow relatively fast, such as pines and eucalyptus. In both softwoods and hardwoods, juvenile wood cells are generally smaller and thinner than in mature wood, and this reflects on their density and mechanical resistance, which should have an effect on the cutting forces developed during processing. The main object of this research was to evaluate orthogonal cutting forces in juvenile and mature Pinus taeda woods. Cutting force magnitude differences were observed for those two regions of the trunk, with parallel cutting forces being $33.4 \%$ higher, on average, at the mature wood region for $90-0$ cutting, and $12 \%$ higher for $90-90$ cutting. This result is consistent with the distinct anatomical structures of the material, since the forces developed during machining depend directly upon its properties.

Key words: wood machining, softwood, plantation wood, cutting optimization
\end{abstract}

\section{FORÇAS DE CORTE ORTOGONAL NA MADEIRA JUVENIL E ADULTA DE PINUS TAEDA}

\begin{abstract}
RESUMO: As características distintas dos lenhos juvenil e adulto, existentes principalmente na formação das coníferas, influenciam na usinagem devido às diferentes propriedades de resistência mecânica ao corte. No passado, quando a maior parte da madeira utilizada industrialmente era proveniente de árvores adultas de florestas naturais, pouca importância era dada à diferenciação de zonas no tronco. Atualmente, no entanto, com o decréscimo constante do suprimento de árvores adultas de grandes diâmetros, provenientes de florestas nativas, tornou-se comum o aproveitamento da madeira de ciclos curtos, através da adoção de espécies de crescimento relativamente rápido, como exemplo os Pinus e os eucaliptos. Tanto nas coníferas quanto nas dicotiledôneas, as células da madeira juvenil são, geralmente, menores e mais delgadas do que na madeira adulta, refletindo em sua densidade e resistência, o que deverá afetar as forças de corte desenvolvidas durante o processamento. O objetivo principal desta pesquisa foi avaliar as forças de corte ortogonal nas madeiras juvenil e adulta de Pinus taeda. Houve diferenças de magnitude das forças de corte nessas duas regiões, sendo as forças de corte paralela, em média, 33,4\% maiores na zona de madeira adulta, no corte $90-0$, e $12 \%$ maiores no corte 90-90. Esse resultado é coerente com a diferenciação da estrutura anatômica do material, uma vez que as forças geradas durante a usinagem dependem, diretamente, de suas propriedades.

Palavras-chave: usinagem, conífera, madeira de reflorestamento, otimização de corte
\end{abstract}

\section{INTRODUCTION}

In the past, when most of the wood used industrially came from adult trees in natural forests, little importance was given to a distinction between different zones of the tree stem. At present, however, as the supply of mature trees with large diameters from native forests is constantly decreasing, the use of short-cycle trees has become a common practice, through the adoption of species that grow relatively fast, such as Pinus and Eu- calyptus. The chemical, physical, anatomical, and mechanical properties of wood during the initial years of the tree life are different from those of the wood formed during the adult stage. This distinction in properties is more strongly marked for conifers.

Juvenile wood, corresponding to the central region of the tree, is present in an approximately uniform manner in the diameter, extending from the base to the top, and may form part of the sapwood and heartwood in the trunk, when the latter is already present in the tree 
(Krahmer et al.; Cown et al.; apud Palma \& Ballarin, 2002). In both softwoods and hardwoods, juvenile wood cells are generally smaller than those of mature wood, and could be three to four times smaller in softwoods, and twice as small in hardwoods. In addition, cell structure is also different: in juvenile wood there is a greater proportion of thin-walled cells. These characteristics make density and resistance in juvenile wood lower than in mature wood (Haygreen \& Bowyer, 1995), and these differences probably have consequences on cutting forces.

The objective of this research was to evaluate orthogonal cutting forces on juvenile and mature Pinus taeda wood, as well as the influence of parameters such as thickness, rake angle, and cutting direction.

\section{MATERIAL AND METHODS}

An orthogonal ring dynamometer had to be built and calibrated in order to measure the cutting forces. The adopted ring was that proposed by King \& Foschi (1969) (Figure 1), which allowed readings of three cutting force components (parallel, normal, and lateral). Figure 2 illustrates the positioning of the analyzed cutting force components (parallel and normal).

The assays were performed on an Infreza model turret milling machine, which received the cutting accessories and the dynamometer.

The cutting types obey McKenzie's (1960) notation, where the first number represents the angle in degrees between the cutting edge of the tool and the wood grain, and the second indicates the angle in degrees between the cutting direction and the wood grain.

A "knife" type tool was used for the 90-0 cutting and a "tooth" type tool was used for the 90-90 cutting (Figure 3). These cutting bits were adapted to the turret mill with tool-holding fixtures manufactured especially for this purpose (Figure 4).

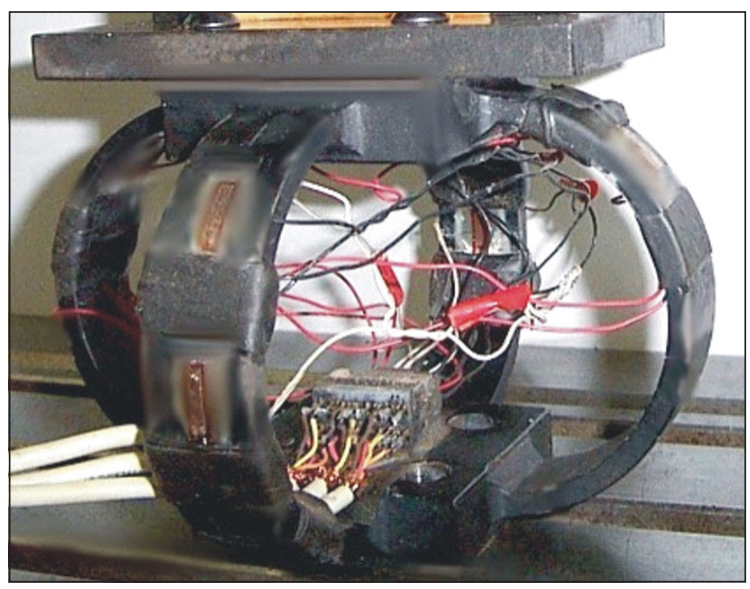

Figure 1 - Ring dynamometer proposed by King \& Foschi (1969) to measure orthogonal cutting forces in wood.
The tool holder was attached to a block (Figure $5)$, which in turn was fixed to the head of the milling machine which defined the angle of attack of the cutting bit, to be adjusted to $10^{\circ}, 20^{\circ}$, and $30^{\circ}$.

A work piece fixture was built to hold the specimens during the assays in the 90-0 condition; the fixture was attached to the dynamometer, which, in turn, was installed onto the rails of the horizontal table of the milling machine. The fixture has an opening in which the specimen is attached (Figure 6).

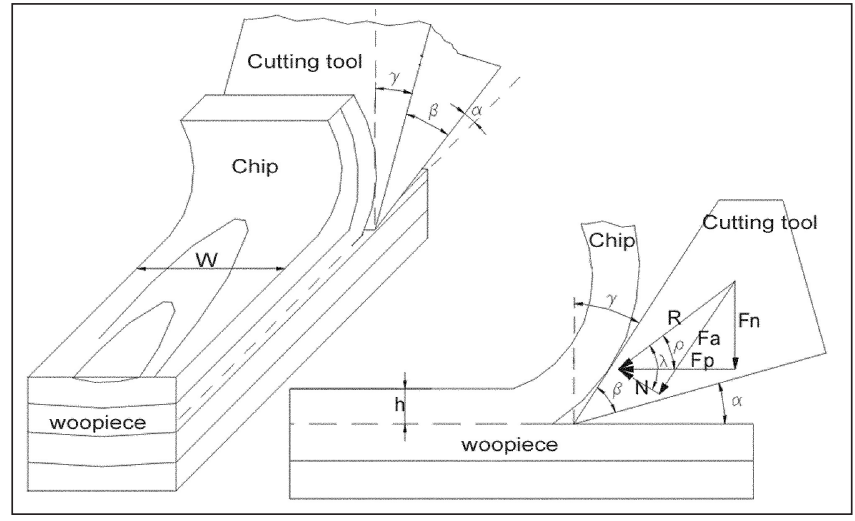

Figure 2 - Cutting angles and force components (Adapted from Woodson \& Koch, 1970).

a)

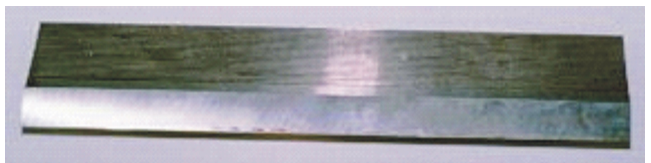

b)

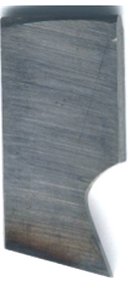

$20^{\circ}$

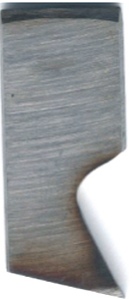

30

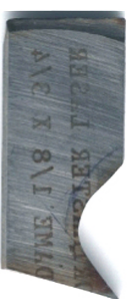

$40^{\circ}$
Figure 3 - Cutting tools used in the 90-0 cuts (a). In this case, the wedge angle was $\beta=30^{\circ}$ and $90-90$ (b).
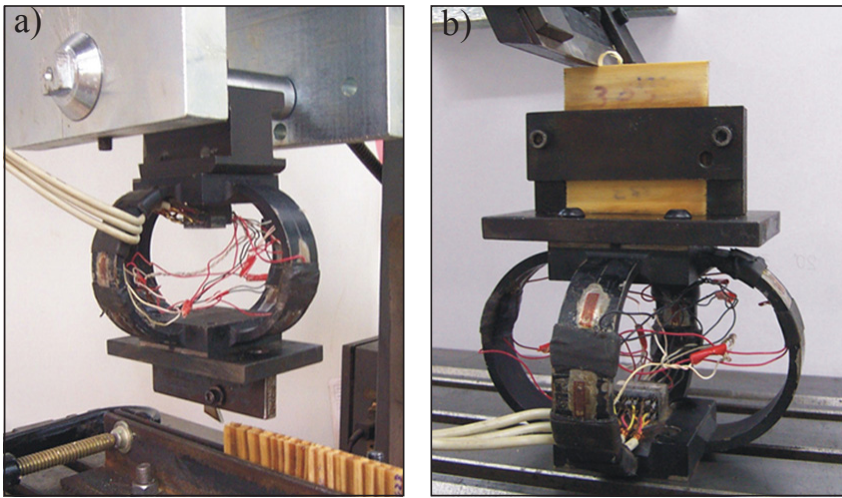

Figure 4 - Specimen holder and tool holding fixtures in the 90-90 (a) and 90-0 (b) cuts. 
Keeping in mind that under the 90-90 situation it is necessary to correct the cutting surface after each stage, performing the assays under the same conditions used during the 90-0 cut would demand much time. Therefore, to optimize the time required to conduct the assay without loss of precision in the results for the 9090 assays, a supporting mount for specimens was built using angle bars and spring clamps. The mount allowed eight specimens to be assayed simultaneously. Thus, the mount was attached to the milling machine table, the dynamometer was attached to the milling machine head, and the tooth-type cutting tool was fastened to the dynamometer (Figure 4a).

The assays for cutting force measurement were made using juvenile and mature Pinus taeda wood specimens, under a saturated condition, in the radial direction (RT plane), and also for the cutting conditions 90-0 and 90-90: cutting depths of $0.2 ; 0.4 ; 0.6 ; 0.8$, and $1.0 \mathrm{~mm}$; tool rake angles (a) of 10,20 , and $30^{\circ}$ for the $90-0$ cutting, and 20,30 , and $40^{\circ}$ for the $90-90$ cutting; cutting speed of $0.32 \mathrm{~m} \mathrm{~min}^{-1}$ with four replicates for each cutting depth and angle.

Observing the chips produced is essential for 90 0 cutting, since they are related to the degree of surface finishing. Therefore, the type of chips produced were observed for this cutting condition.

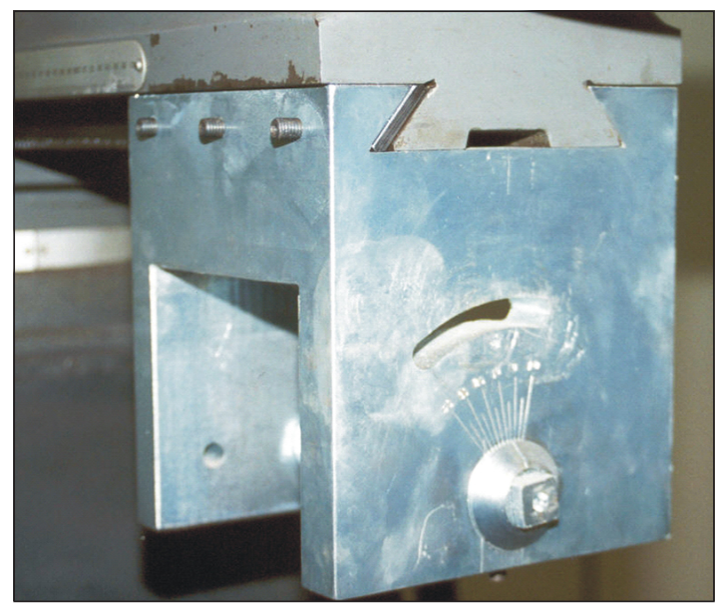

Figure 5 - Tool holding fixture (block).

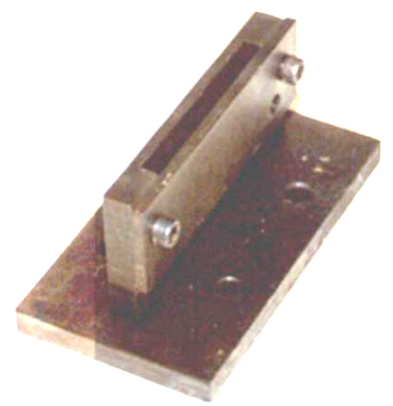

Figure 6 - Fixture for holding 90-0 specimens.
The chips were analyzed using the methodology proposed by Franz (1958), as well as the procedures adopted by Néri et al. $(1999 ; 2000)$. According to these authors, type I chips are formed when the cutting conditions are such that wood breakage is achieved by splitting, on a plane ahead of the cutting tool, and the chip detaches as a cantilever (Figure 7). Type II chips when wood breakage is produced along a line that extends from the cutting edge of the tool. In this case, rupture occurs by shearing and there is the formation of a continuous, strand-like chip (Figure 8). Type II chips are usually associated with a better cutting surface and coincide with a normal cutting force near zero. In type III chips the cutting forces produce breakage by parallel compression and shearing in the wood ahead of the cutting edge of the tool. The chips do not have a defined shape, and are reduced to fragments (Figure 9).

The wood used in this work derived from logs from Pinus taeda L. trees, 37 years old, located in

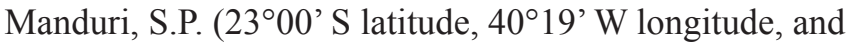
$700 \mathrm{~m}$ elevation) using six trees with a mean commercial height of $18.2 \mathrm{~m}$ and a mean DBH of $0.404 \mathrm{~m}$, selected at random. Four small logs $2.20 \mathrm{~m}$ in length were removed from each tree, at the base of the trunk, totaling 24 small logs.

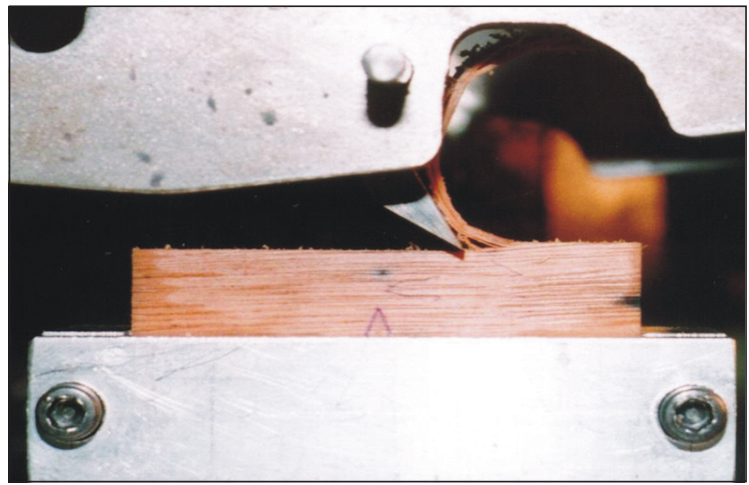

Figure 7 - Type I chip obtained in the 90-0 orthogonal cutting assay. Species: Eucalyptus grandis, cutting thicknesses: $1.52 \mathrm{~mm}$, and angle of attack: $\alpha=30^{\circ}$. (Néri, 1998).

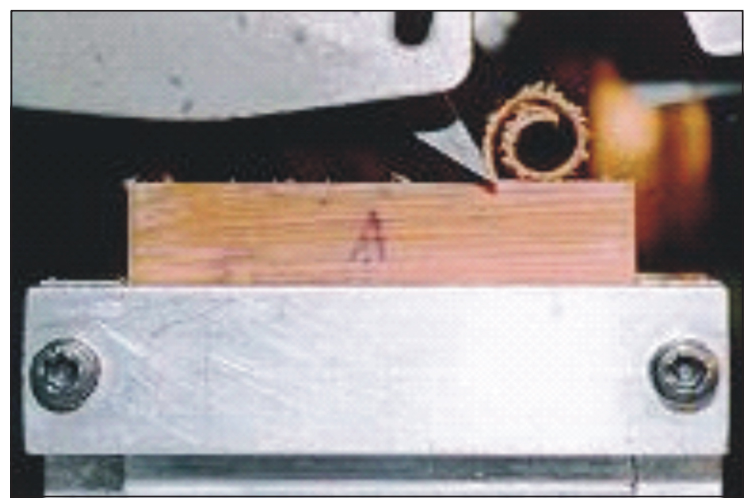

Figure 8 - Type II chip obtained in the 90-0 orthogonal cutting assay. Species: Eucalyptus grandis, cutting thicknesses: $0.38 \mathrm{~mm}$, and angle of attack: $\alpha=30^{\circ}$. (Néri, 1998) 
A cylinder $0.40 \mathrm{~m}$ in length was taken from the upper end of each small log, sawn into parts measuring $0.40 \mathrm{~m} \times 0.15 \mathrm{~m}$, for later removal of specimens (Figure 10). The 24 pieces were partitioned, and moisture content was kept above the fiber saturation point. Four other pieces measuring $0.40 \times 0.08 \times 0.007 \mathrm{~m}$ for the $90-0$ cutting and $0.40 \times 0.08 \times 0.01 \mathrm{~m}$ for the $90-90$ cutting were taken from each $0.40 \times 0.15 \mathrm{~m}$ piece, always observing the slope of the growth rings, fiber alignment, and the juvenile and mature wood regions.

Each piece received a code consisting of numbers and letters. The first two codes indicated the tree and position in the trunk, while the last two indicated whether it was juvenile or mature wood and the type of cutting, either $90-0$ or 90-90, respectively. All pieces were regularized at the final width and thickness for the specimen, and ultimately cut into $0.075 \times 0.075 \times 0.006 \mathrm{~m}$ for the $90-0$ cutting and $0.075 \times 0.075 \times 0.009 \mathrm{~m}$ for the $90-90$ cutting. These dimensions were adopted after a preliminary study about the magnitude of the cutting forces generated during the assay, since the highest cutting force should be compatible with the dynamometer load capacity.

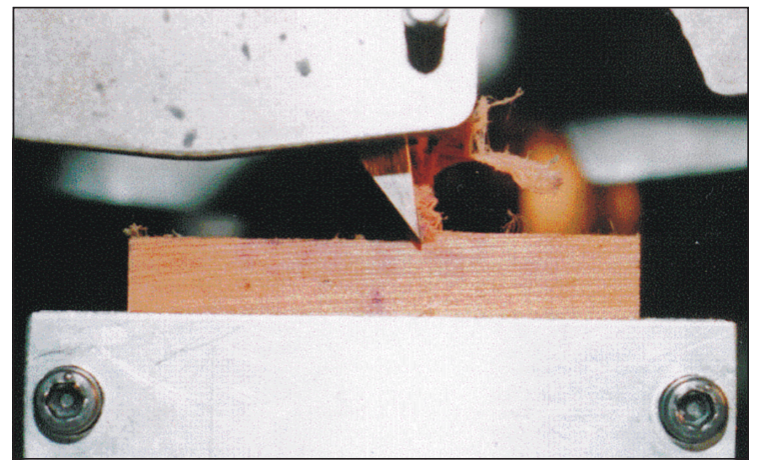

Figure 9 - Type III chip obtained in the 90-0 orthogonal cutting assay. Species: Eucalyptus grandis, cutting thicknesses: $1.52 \mathrm{~mm}$, and angle of attack: $\alpha=10^{\circ}$. (Néri, 1998).
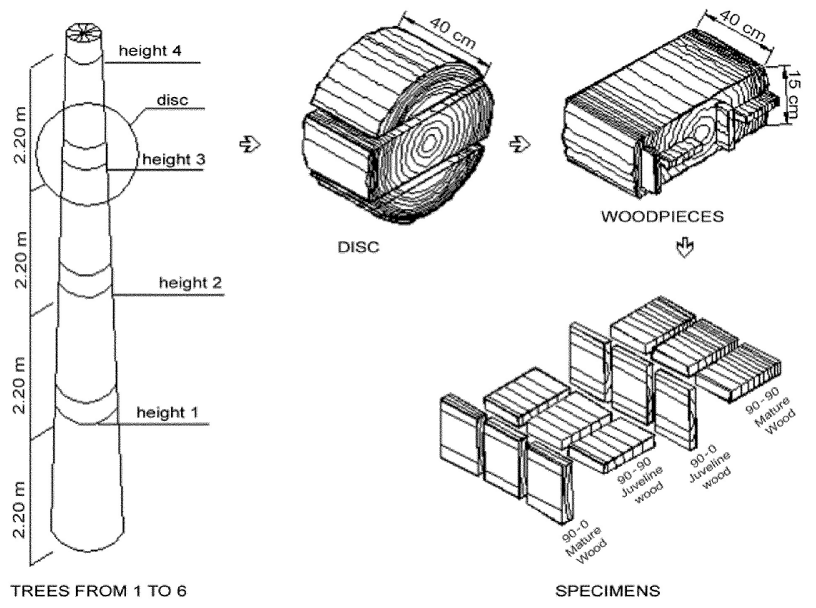

Figure 10 - Scheme for removal of specimens.
The specimens were then placed inside a freezer to maintain moisture above the fiber saturation point. Approximately one hour before the assay, the specimens were removed from the freezer and maintained in sealed plastic bags, from which they were removed for the assay. This procedure allowed the specimens to thaw without excessive loss of moisture. Figure 11 presents a scheme for the specimens with their dimensions and orientation. For the 90-0 cutting, the tool edge was parallel with the radial axis and the cutting direction was L (LR Plane), while in the 90-90 cutting the tool edge was parallel with $\mathrm{T}$ and the cutting direction was $\mathrm{R}$ (TR Plane).

The demarcation of juvenile and mature wood was performed on the segments of the six logs that were not used to make specimens (Palma \& Ballarin, 2002). In order to accomplish the demarcation, one disc was removed from each tree at breast height; macerated material was obtained from the disc to determine axial tracheids length (microscopic method). In the anatomical study, the recommendations of Franklin's modified method, apud Taylor (1975), and of the ABNT-IAWA norm (1994) were followed. The juvenile wood region in those trees occurred approximately until the $18^{\text {th }}$ growth ring, and was more representative until the $14^{\text {th }}$ ring. The transition region occurred between the $14^{\text {th }}$ and the $18^{\text {th }}$ growth rings. Figure 12 shows the demarcations for juvenile wood, transition wood, mature wood, and also the position from which specimens were taken from each zone.
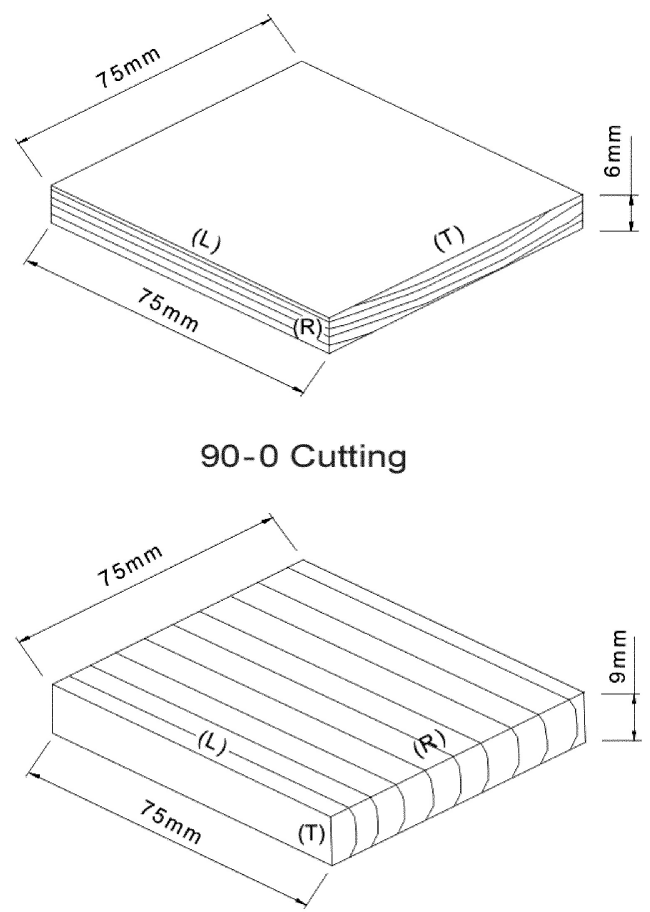

\section{0-90 Cutting}

Figure 11 - Dimensions and orientation of specimens according to each direction and cutting type. $\mathrm{L}=$ longitudinal direction; $\mathrm{R}=$ radial direction, and $\mathrm{T}=$ tangential direction . 


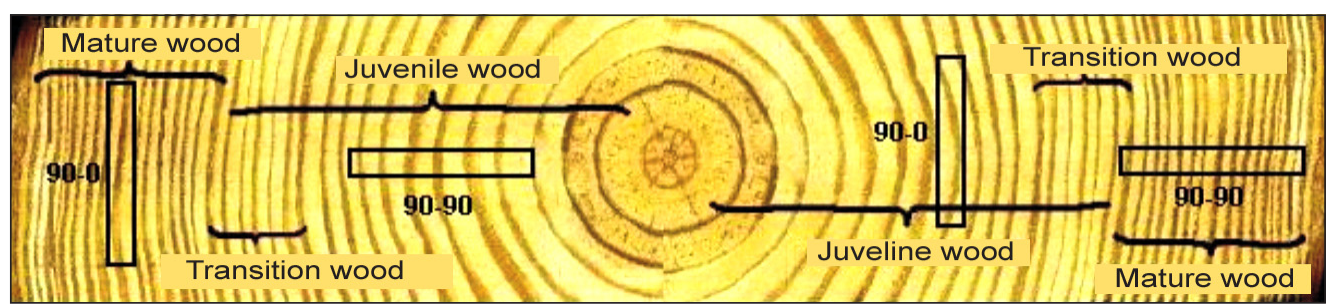

Figure 12 - Demarcation of juvenile, transition, and mature wood, and positions from which specimens were taken.

In order to acquire cutting force data, a Model HBM AB22A, MGC Plus piece of equipment with 14 input and output data acquisition channels was used. The cutting force signals were read as $\mathrm{mV}$ (millivolt) with a $0.001 \mathrm{mV}$ precision.

A total of 5,760 cutting force measurement assays were performed (96 specimens, each assayed at three different angles and five cutting thickness, two cutting types (90-0 and 90-90), and two regions - juvenile and mature) for Pinus taeda, and the maximum, medium, and minimum values for parallel and normal forces were later calculated.

The presentation and discussion of results were based on mean values. Even though the minimum and maximum forces were calculated, they were not presented or discussed in this work. The minimum force was not discussed because it lacks of practical interest, since its values are significantly affected by any small existing defect; the maximum force was not discussed because it is more directly concerned with research related to machine power determination, which is an aspect that was not the object of this work.

Initially, the mean values obtained for each situation under study (cutting type and angle, mature or juvenile zone) were plotted on graphs and the behavioral trend of the forces (parallel and normal) was observed. In these graphs, each cutting force represents the mean obtained from the assay that involved twenty and four specimens with four replicates, that is, four cutting passes per specimen under each cutting condition.

Statistical tests were applied to evaluate the difference between cutting force obtained for the mature and juvenile zones. Initially, by means of a Box Plot graph and based on the median and dispersion of data, it was verified whether the parallel and normal cutting forces in the juvenile and mature wood zones presented different behavior. The " $\mathrm{t}$ " test was applied to compare the mean cutting forces in juvenile and mature wood, in order to confirm the trend indicated by the Box Plot graph.

\section{RESULTS AND DISCUSSION}

The graphs in Figure 13 show the behavior of mean parallel and normal cutting forces in Pinus taeda mature and juvenile wood, as a function of cutting parameters (angle and thickness). The machines used in planning and veneer production operations work under conditions very similar to the $90-0$ orthogonal cutting. The main characteristic in this type of cutting is the formation of chips that define the degree of finishing of the machined surface. Normal forces near zero provide the formation of type II chips, which coincide with the best finishing degree (Franz, 1958). In this case, because there is great interest in the quality of the cutting surface, the energy required for cutting is not as important as determining the ideal cutting conditions for type II chip formation.

During the 90-0 cutting assays with the Pinus taeda species, for the three angles of attack, $10^{\circ}, 20^{\circ}$, and $30^{\circ}$, the formation of type II chips was predominant at all cutting thicknesses, with occasional cases of formation of type I and type III chips, in both juvenile and mature wood. Since the 90-0 cutting was performed for situations at an angle of attack between $10^{\circ}$ and $30^{\circ}$, this result was compatible with the definitions by Franz (1958), which indicates the occurrence of type II chips at intermediate rake angles of a tool, type I chips at high angles (greater than $30^{\circ}$ ), and type III chips at angles below $10^{\circ}$. Under the same cutting conditions in assays involving Eucalyptus species (grandis, saligna, and citriodora), the results obtained by Néri et al. (1999) demonstrated that, on average, for all thicknesses, type III chips were predominant at a $10^{\circ}$ angle, type II at a $20^{\circ}$ angle, and type I at a $30^{\circ}$ angle.

At the studied angles, Pinus taeda presented a better machining ability than Eucalyptus grandis, saligna and citriodora species, i.e., it is easier to obtain pieces with a better surface finishing using $P$. taeda, at the cutting tool angle interval between $10^{\circ}$ and $30^{\circ}$, since the predominant chip type was type II.

\section{Normal force}

For the six studied Pinus taeda trees, the normal cutting force was always positive, at all angles and thicknesses, for both the juvenile and mature wood zones. Positive normal cutting forces indicate that, in relation to the cutting plane, the knife tends to press or penetrate into the specimen. In addition, positive normal forces occur in association with type II chips. At the $10^{\circ}$ angle, the normal forces increased as cutting thickness increased, both for juvenile and mature wood, indicating that at small angles the normal force is more significantly influ- 
enced by the cutting thickness (Figures 13e and 13f). At $20^{\circ}$ and $30^{\circ}$ the mean normal force showed little variation as thickness increased, both for juvenile and mature wood. In both regions (mature and juvenile) there were some transition cases in the formation of chips between the $20^{\circ}$ and $30^{\circ}$ angles, which went from type II to type I. This transition is associated with a decrease in cutting forces, reflected on the graphs of Figures 12e and 12f.
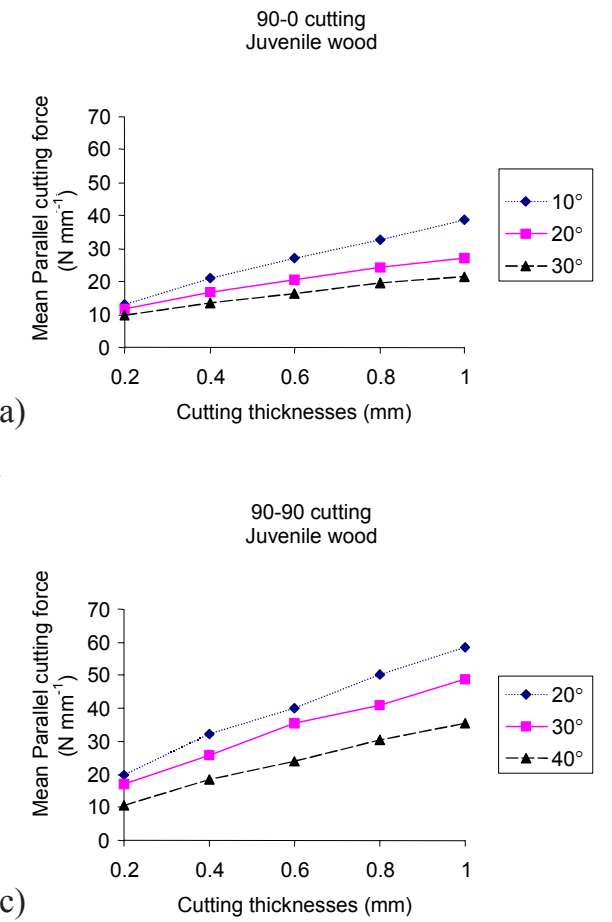

c)

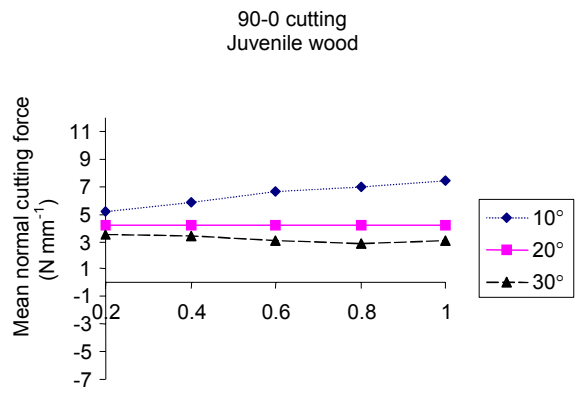

e)

$$
\text { Cutting thicknesses }(\mathrm{mm})
$$

90-90 Cutting

Juvenile wood

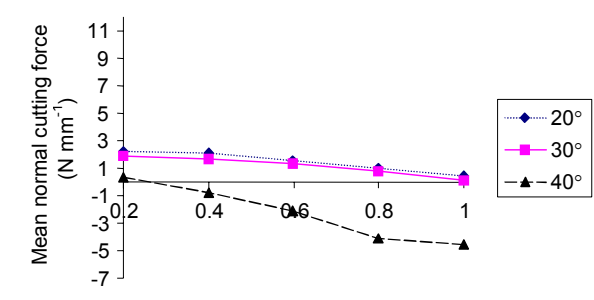

g)

Cutting thicknesses (mm)
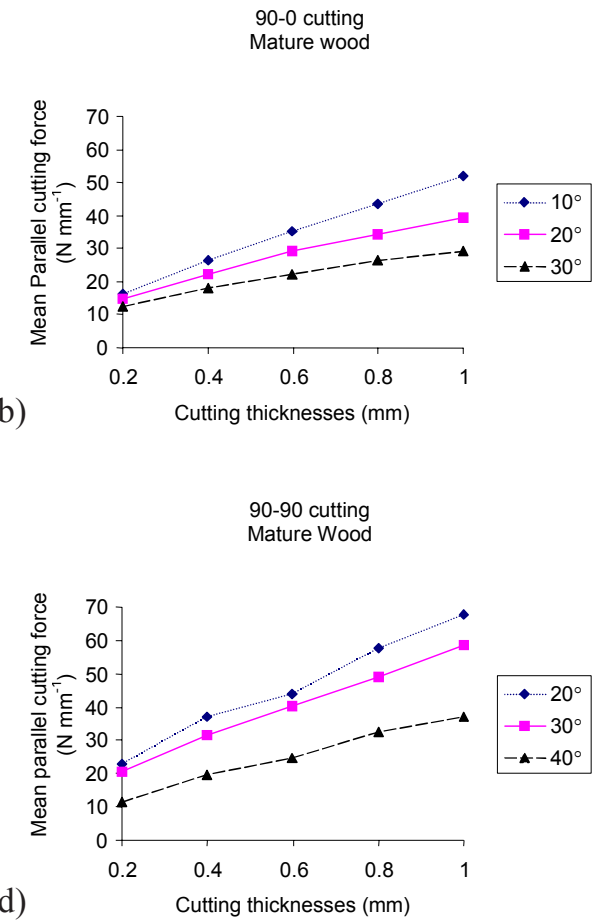

d)

$90-0$ cutting
Mature wood

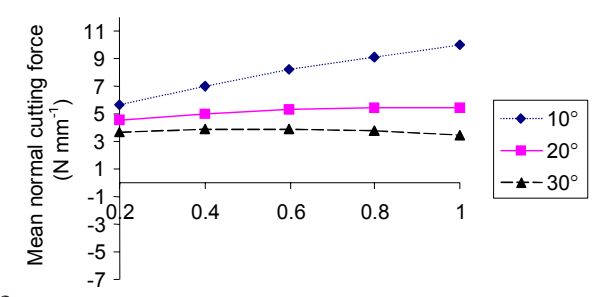

f) Cutting thicknesses $(\mathrm{mm})$

90-90 Cutting

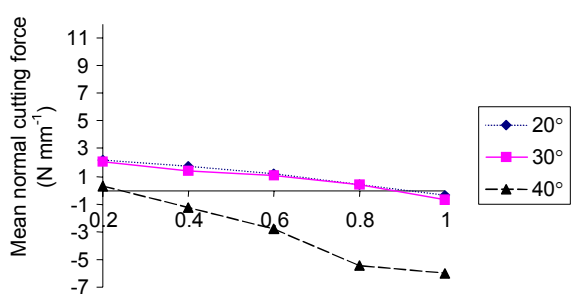

h)

Cutting thicknesses $(\mathrm{mm})$

Figure 13 - Mean normal and parallel cutting forces in relation to the angle of attack and thickness, for 90-0 and 90-90 cuttings, in juvenile and mature wood. (a) parallel force, 90-0 cutting, juvenile wood; (b) parallel force, 90-0 cutting, mature wood; (c) parallel force, 90-90 cutting, juvenile wood; (d) parallel force, 90-90 cutting, mature wood; (e) normal force, 90-0 cutting, juvenile wood; (f) normal force, 90-0 cutting, mature wood; (g) normal force, 90-90 cutting, juvenile wood; (h) normal force, 90-90 cutting, mature wood. 


\section{Parallel force}

For both juvenile and mature wood, the parallel forces presented a compatible behavior with what was expected, always increasing as cutting thickness increased and angle of attack decreased (Figures 13a to 13d).

90-90 orthogonal cutting - Band saws are an example of a wood processing machine that works in a 9090 cutting situation when the cutting blade acts in a parallel direction in relation to the transversal section. The 90-90 orthogonal cutting is characterized by producing type I and II failures on the machined surface, as well as by high parallel cutting forces in relation to 90-0 cutting. In type I failures, the cutting surface is less affected than in type II. In 90-90 cutting, the cutting surface finish is not as important as in the case of 90-0 cutting. On the other hand, the magnitude of the parallel force and the configuration of the cutting tool are, in this case, extremely important.

\section{Normal force}

For juvenile and mature Pinus taeda woods, the mean normal force decreased as cutting thickness and angle increased, going from positive to negative between angles of $30^{\circ}$ and $40^{\circ}$ (Figures $13 \mathrm{~g}$ and $13 \mathrm{~h}$ ). Since a normal force equal to zero is associated with the best cutting surfaces, it is possible to estimate the ideal angle of attack by observing in the graph where the normal force passes across the axis. In both juvenile and mature wood, the normal force was near zero for the $40^{\circ}$ angle and a cutting thickness smaller than $0.4 \mathrm{~mm}$ (Figures $13 \mathrm{~g}$ and 13h). The same condition was observed for mature wood at the $20^{\circ}$ and $30^{\circ}$ angles, but thicknesses higher than 0.8 $\mathrm{mm}$ (Figure 13h).

The mean normal forces for the 90-90 cutting were negative in some cases (Figures $13 \mathrm{~g}$ and $13 \mathrm{~h}$ ). The mean normal forces must be positive in woods with basic densities lower than $500 \mathrm{~kg} \mathrm{~m}^{-3}$, and negative in woods with basic densities higher than $500 \mathrm{~kg} \mathrm{~m}^{-3}$ (Woodson, 1979). Néri et al., 2000 challenged this statement, by mentioning that it might not be possible to define precisely the density limit of $500 \mathrm{~kg} \mathrm{~m}^{-3}$ for the normal force signal to change. In this work, such questioning was once again ratified, since although the density of the Pinus taeda was very close to this limit $\left(420 \mathrm{~kg} \mathrm{~m}^{-3}\right.$ for juvenile wood and $470 \mathrm{~kg} \mathrm{~m}^{-3}$ for mature wood), the normal forces were not always positive.

\section{Parallel force}

The mean parallel force had a similar behavior in the juvenile and mature wood zones, increasing as cutting thickness increased and decreasing as the angle of attack increased. The relations between mean parallel force and thickness and evacuation angles have an approximately linear behavior, for both the juvenile and mature wood zones.

\section{Cutting force values}

For the Pinus taeda tested in this work, considering all angles, thicknesses and juvenile and mature wood zones, the mean parallel cutting force was 24.63 $\mathrm{N} \mathrm{mm}^{-1}$ in the 90-0 cutting, and $35.42 \mathrm{~N} \mathrm{~mm}^{-1}$ in the 9090 cutting. Woodson \& Koch (1970) determined the cutting forces for initial and final Pinus taeda woods under the 90-0 and 90-90 cutting situations, radial direction, and saturated wood, also taking into consideration all angles, cutting thicknesses, and initial and final woods, and obtained mean parallel cutting force values of $22.3 \mathrm{~N} \mathrm{~mm}^{-1}$ for $90-0$ cutting, and $34.7 \mathrm{~N} \mathrm{~mm}^{-1}$ for $90-90$ cutting. Néri et al. (1999) determined the cutting forces for three eucalyptus species (grandis, saligna, and citriodora). For the 90-0 cutting of the grandis species, whose density is close to that of the species here studied, the mean parallel cutting force at the $10^{\circ}$ angle, in all thicknesses, was 33.2 $\mathrm{N} \mathrm{mm}{ }^{-1}$. The mean parallel cutting force for the same angle $\left(10^{\circ}\right)$ and same cutting type (90-0), taking all thicknesses into consideration, was $35.8 \mathrm{~N} \mathrm{~mm}^{-1}$. Gonçalves, cited by Tibúrcio (2000), determined the cutting force for the species Pinus elliottii, in the 90-0 cutting at a $10^{\circ}$ angle. The mean parallel cutting force was $27.42 \mathrm{~N} \mathrm{~mm}^{-1}$ for cutting thicknesses of $0.2 \mathrm{~mm} ; 0.4 \mathrm{~mm}$; and $0.6 \mathrm{~mm}$. For our Pinus taeda, at the same angle and taking the same thickness into consideration, the mean parallel force value was $23.23 \mathrm{~N} \mathrm{~mm}^{-1}$. Toro et al. (2002) determined the cutting forces for Pinus radiata and found, for the 900 cutting in the radial direction, taking all cutting thicknesses into consideration, a mean parallel force value of $41.38 \mathrm{~N} \mathrm{~mm}^{-1}$ at the $20^{\circ}$ angle, and $27.88 \mathrm{~N} \mathrm{~mm}^{-1}$ at the $30^{\circ}$ angle. In this work, the mean parallel force was 24.01 $\mathrm{N} \mathrm{mm}^{-1}$ at the $20^{\circ}$ angle, and $19.22 \mathrm{~N} \mathrm{~mm}^{-1}$ at the $30^{\circ}$ angle.

Therefore, the mean parallel force values for Pinus taeda here obtained differ from those obtained by Woodson \& Koch (1970) by about 10\% for the 90-0 cutting and about $2 \%$ for the $90-90$ cutting, and by about $7.8 \%$ from those obtained by Néri et al. (1999). In the case of the work by Gonçalves, cited by Tiburcio (2000), the parallel force difference in relation to this work was a little higher $(18 \%)$. In relation to the results obtained by Toro et al. (2002), differences were high (72\% for the $20^{\circ}$ angle and $45 \%$ for the $30^{\circ}$ angle).

This comparison allows to draw the conclusion that these results are compatible, in order of magnitude, with those obtained by other authors in similar reports, especially in the case of Woodson \& Koch, who used the same Pinus. In the case of Néri et al. (1999) and Gonçalves, cited by Tiburcio (2000), although other species were used, differences were also small. With regard to the results by Toro et al, however, differences were high and are probably related to the conditions in the assay (different methodology) or wood moisture conditions, since these details were not mentioned in the article. 
Comparison of cutting forces at different trunk heights

The mean values obtained in the assays, as well as a summary of the results from the statistical test are presented in Table 1. In this table, each value corresponds to a mean of 540 assays. Initially, it was observed from the Box Plot graph that the median and dispersion for cutting force data were similar in all positions established along the trunk height, for the 90-0 and 90-90 cuttings.

The hypothesis established for the statistical analysis of cutting forces at different trunk heights, was that they were not different in the direction from the trunk base toward the apex. The " $t$ " test to compare means between positions 1 and 4, with $\alpha=5 \%$, resulted in the acceptance of the hypothesis $\left(\mathrm{t}_{\text {calculated }}<\mathrm{t}_{\text {crit }}\right.$ ), except for the normal force in the 90-0 cutting. In the same way, the interval of confidence of differences between means, obtained at the four positions, showed no difference among them, since this interval contains zero, that is, a null difference cannot be rejected. Thus, the mean forces in $90-$ 0 and 90-90 cuttings were not different for the four different heights, except for the normal force in the 90-0 cutting. This result could be attributed to the age of the trees ( 37 years), because, in this case, all positions would have similar properties.

\section{Differences between cutting force in juvenile and ma- ture wood zones}

The mean parallel and normal cutting forces for 90-0 and 90-0 cuttings, in juvenile and mature wood, as well as the summary for the mean comparison statistical analysis, are presented in Table 2 . In this table, each value corresponds to a mean of 1,080 assays. The hypothesis for this comparison is that no significant difference exists between cutting force means obtained for juvenile and mature woods.

Table 1 - Mean cutting force at different trunk heights (Figure 10) and summary of the mean comparison statistical analysis.

\begin{tabular}{|c|c|c|c|c|c|}
\hline Cutting & Force & Position on the trunk & Mean & $\mathrm{t}_{\text {calculated }}$ & Confidence interval of differences between means \\
\hline \multirow{9}{*}{$90-0$} & \multirow{5}{*}{ Parallel } & & $\mathrm{N} \mathrm{mm}^{-1}$ & & $\mathrm{~N} \mathrm{~mm}^{-1}$ \\
\hline & & Height 1 & 24.39 & & \\
\hline & & Height 2 & 24.52 & 0.311 & -1.239 to 1.705 \\
\hline & & Height 3 & 25.51 & & \\
\hline & & Height 4 & 24.16 & & \\
\hline & \multirow{4}{*}{ Normal } & Height 1 & 5.22 & & \\
\hline & & Height 2 & 5.11 & 2.725 & 0.115 to 0.709 \\
\hline & & Height 3 & 5.44 & & \\
\hline & & Height 4 & 4.81 & & \\
\hline \multirow{8}{*}{$90-90$} & \multirow{4}{*}{ Parallel } & Height 1 & 35.22 & & \\
\hline & & Height 2 & 35.77 & 0.533 & -2.072 to 3.618 \\
\hline & & Height 3 & 36.22 & & \\
\hline & & Height 4 & 34.45 & & \\
\hline & \multirow{4}{*}{ Normal } & Height 1 & -0.25 & & \\
\hline & & Height 2 & -0.31 & 0.116 & -0.631 to 0.382 \\
\hline & & Height 3 & -0.34 & & \\
\hline & & Height 4 & -0.12 & & \\
\hline
\end{tabular}

Table 2 - Mean cutting force for juvenile and mature woods and summary of the mean comparison statistical evaluation.

\begin{tabular}{|c|c|c|c|c|c|}
\hline Cutting & Force & Region & Mean & $\mathrm{t}_{\text {calculated }}$ & Confidence interval of differences between means \\
\hline \multirow{5}{*}{$90-0$} & & & $\mathrm{~N} \mathrm{~mm}^{-1}$ & & $\mathrm{~N} \mathrm{~mm}^{-1}$ \\
\hline & \multirow{2}{*}{ Parallel } & Mature & 28.16 & \multirow{2}{*}{13.72} & \multirow{2}{*}{6.06 to 8.09} \\
\hline & & Juvenile & 21.11 & & \\
\hline & \multirow{2}{*}{ Normal } & Mature & 5.63 & \multirow{2}{*}{9.30} & \multirow{2}{*}{0.81 to 1.24} \\
\hline & & Juvenile & 4.64 & & \\
\hline \multirow{4}{*}{$90-90$} & \multirow{2}{*}{ Parallel } & Mature & 37.38 & \multirow{2}{*}{3.81} & \multirow{2}{*}{1.91 to 5.96} \\
\hline & & Juvenile & 33.45 & & \\
\hline & \multirow{2}{*}{ Normal } & Mature & -0.45 & \multirow{2}{*}{-2.13} & \multirow{2}{*}{-0.74 to -0.03} \\
\hline & & Juvenile & -0.06 & & \\
\hline
\end{tabular}


By means of a Box Plot graph and based on the median and dispersion of the data, it was observed that the parallel and normal cutting forces in the juvenile and mature wood zones had different behavior. The same observation can be made from the results presented in Table 2 , where it can be clearly verified that the parallel and normal cutting force means are higher for mature wood.

The "t" test to compare means between cutting forces obtained for juvenile and mature wood, with $\alpha=$ $5 \%$, resulted in the rejection of the $\left(\mathrm{t}_{\text {calculated }}>\mathrm{t}_{\text {crit }}\right)$ hypothesis in all cases. In the same way, the confidence interval of differences between means, obtained at the four positions, indicated that there were differences among them, since this interval does not contain zero. The parallel force was, on average, $33.4 \%$ higher for mature zone wood for the $90-0$ cutting, and $12 \%$ higher for the $90-90$ cutting (Table 2). This result is attributed to the anatomical differences of the wood in juvenile and mature zones, i.e., considering that juvenile wood presents lower density and lower resistance, and that cutting forces are directly related to these parameters, the normal and parallel cutting forces were smaller in this region.

\section{ACKNOWLEDGEMENTS}

To FAPESP for funding the research and to CAPES for granting a scholarship.

\section{REFERENCES}

ABNT-IAWA. Título da norma ou normas usadas. International Association of Wood Anatomists. Leiden, 1994.
FRANZ, N.C. An Analysis of the wood-cutting process. Ann Arbor: University of Michigan, 1958. 152p. (PhD-Thesis).

HAYGREEN, J.G.; BOWYER, J.L. Forest products and wood science. Ames: Iowa State University Press, 1995.

KING, B.; FOSCHI, R.O. Crossed-Ring dynamometer for direct force resolution into three orthogonal components. International Journal of Machine Tool Design Research, v.9, p.345-356, 1969.

McKENZIE, W.M. Fundamental aspects of the wood cutting process. Forest Products Journal, v.10, p.447-456, 1960.

NÉRI, A.C. Medidas de forças de corte na madeira de eucalipto. Campinas: UNICAMP/FEA, 1998. 152p. (Dissertação - Mestrado).

NÉRI, A.C.; GONÇALVES, R.; HERNANDEZ, R.E. Forças de corte ortogonal 90-0 em três espécies de madeira de eucalipto. Revista Brasileira de Engenharia Agrícola e Ambiental, v.3, p.239-244, 1999.

NÉRI, A.C.; GONÇALVES, R.; HERNANDEZ, R.E. Forças de corte ortogonal 90-90 em três espécies de madeira de eucalipto. Revista Brasileira de Engenharia Agrícola e Ambiental, v.4, p.275-280, 2000.

PALMA, H.A.L.; BALLARIN, A.W. Demarcação e densidade de madeira juvenil e adulta para o Pinus taeda L. In: ENCONTRO BRASILEIRO EM MADEIRAS E EM ESTUTURAS DE MADEIRA, 8., Uberlândia, 2002. CD-Rom.

TAYLOR, F.W. Fiber length measurement - an accurate inexpensive technique. Tappi, v.58, p.126-127, 1975.

TIBURCIO, U.F.O. Aplicação do método de "KIENZLE” em experimentos de usinagem da madeira para determinação da pressão específica de corte. Bauru: UNESP/FEB, 2000. 55p. (Dissertação - Mestrado).

TORO, W.M.; LARA, C.M.; MAC-CARTE, G.V. Estimacion y modelamiento estadistico para la fuerza resultante de corte 90-0 em madera de Pinus radiata. In: CONGRESSO IBERO-AMERICANO DE PESQUISA E DESENVOLVIMENTO DE PRODUTOS FLORESTAIS, Curitiba, 2002. CD-Rom.

WOODSON, G.E. Tool forces and chip types in orthogonal cutting of southern hardwoods. Washington: USDA, Forest Service, 1979. (Research Paper SO, 146).

WOODSON, G.E.; KOCH, P. Tool forces and chip formation in orthogonal cutting of loblolly pine. Washington: USDA, Forest Service, 1970. (Research Paper SO, 52).

$\overline{\text { Received October }}$ 17, 2003

Accepted May 02, 2005 